\title{
フグはなぜ自分のフグ毒に 中毒しないのか
}

フグ毒はヒトをはじめほとんどの動物に神経毒として作用するのに，フグ自身が中毒しないのはなぜか？ 最近 の研究成果から, この毒に対する耐性機構には標的分子 $\mathrm{Na}$ チャンネル中のある限られた部位の变異が深く関わ っていることがわかってきた. さらにフグの筋肉中には， $\mathrm{Na}$ チャンネル以外にもテトロドトキシン結合能をも つタンパク質の存在も指摘されており, 複数の機構で自分を守っているのかもしれない.

\section{フグ毒と Na チャンネル}

昨今，人工の神経毒サリンが社会を騒がせてい るが，フグ毒テトロドトキシン (TTX) は代表的 な天然の神経毒である。 そのターゲット分子が， 神経細胞や筋細胞などの 細胞膜（いわゆる興奮 膜）に高密度で存在する $\mathrm{Na}$ チャンネルである.

この $\mathrm{Na}$ チャンネルは細胞膜の電位がある值以上 に達すると開口する “電位依存性イオンチャンネ ル”であり，上記の細胞に活動電位と呼ばれる電 気インパルスを発生させる. したがって, 生物個 体内の迅速な刺激伝達の際に中心的な役割を果た している. 今日, $\mathrm{Na}$ チャンネルの分子構造につ いては，後述のように，かなり詳しくわかってき て怙り,この研究過程で TTX が果たした役割は 計りしれないものがある(1). 1950 年代, Hodgkin と Huxley の電気生理学研究に基づく「神経興奮 の $\mathrm{Na}$ イオン説」の提唱や, その後の薬理学, 生 化学分野での展開に括いても，TTX は不可欠な “分子ッール”であった. そして, 1984 年には, $\mathrm{Na}$ チャンネル分子の一次構造が明らかにされる に至った。

“フグ毒”と呼ばれているこ とからあわかるように，TTX はある種のフグの卵巣や肝臓に かなり高濃度に含まれる.その

Why Puffer Fishes Are Not Intoxicated by Their Carring Tetrodotoxin? * Hitoshi NAKAYAMA, 熊本大学楽 学部
研究の歴史は古く, フグ卵巣からの TTX の抽出 はすでに 1894 年に, 田原良純博士らによって報 告されている(2). ところで, TTX あるいはとの 同族体はフグだけではなく，ツムギハゼ，七ョウ モンダュ, スベスベマンジュウガニやカリフォル ニアイモリなどにむ見いだされている．このこと からあ，TTX はフグ自身が生合成するのではな いことが推測されたが，実際に，ビブリオ属，ア ルテロモナス属などの細菌が生産することがわか ってきている.これらの細菌を含むプランクトン や海藻を食したフグなどが担毒動物となる可能性 が考光られて拈り，これらに関するわかりやすい 解説むある(3). したがって，TTX の話を進める 上では，当然フグ以外の TTX（扣よびその同族 体）を体内にもつ動物も考慮する必要があるが， 本稿では “フグ毒”と呼ばれることに敬意を表し て，フグについてのみ記述することにする.

さて, $\mathrm{Na}$ チャンネルは神経伝達を担ら基本分 子であるから, 当然フグの神経や筋肉組織にも存 在する、にもかかわらず，なぜフグは TTX で中 毒しないのであろらか？この問いに対する現時 点での有力な答えは，次の 2 つであろう，第一

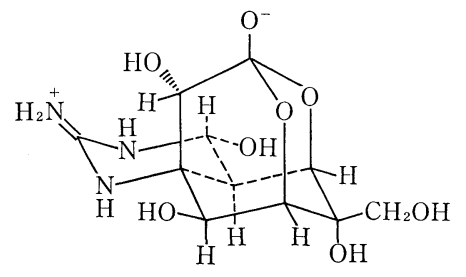

テトロドトキシン

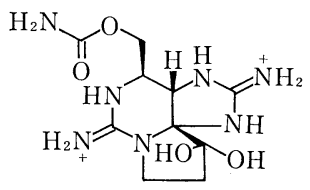

サキシトキシン 
は, $\mathrm{Na}$ チャンネルの分子構造が TTX 感受性を 示す他の動物とは異なっているとする考えであ り，第二は，フグには TTX と結合することによ ってその毒作用の発現を抑觉るタンパク質が存在 するとの考觉である、本稿では，私見む交じえな がらこれらの内容を紹介してみたい。

\section{$\mathrm{Na}$ チャンネルの分子構造}

$\mathrm{Na}$ チャンネルは, 1984 年に電気ウナギの発電 器官 (発生学的には筋肉組織) から mRNA の cDNA が初めてクローニングされ，そのアミノ 酸配列が明らかにされた。その解析結果より, $\mathrm{Na}$ チャンネルは膜に対して，図１に示すような配 置をしているとするモデルが受け入れられてい る(1). 6つの異なった膜貫通セグメント（S 1〜 S6）が1つのドメイン（またはモチーフ）をつ くり，このドメイン構造が 4 回くり返される. し たがって，このドメインはリピート $(I \sim \mathbb{N})$ と 呼ばれる.

さて，Na チャンネルには TTX 感受性のもの と, 感受性が低いもの（ここでは便宜上 “非感受 性”と呼ぶ）の 2 種類がある. 前述の電気ウナギ

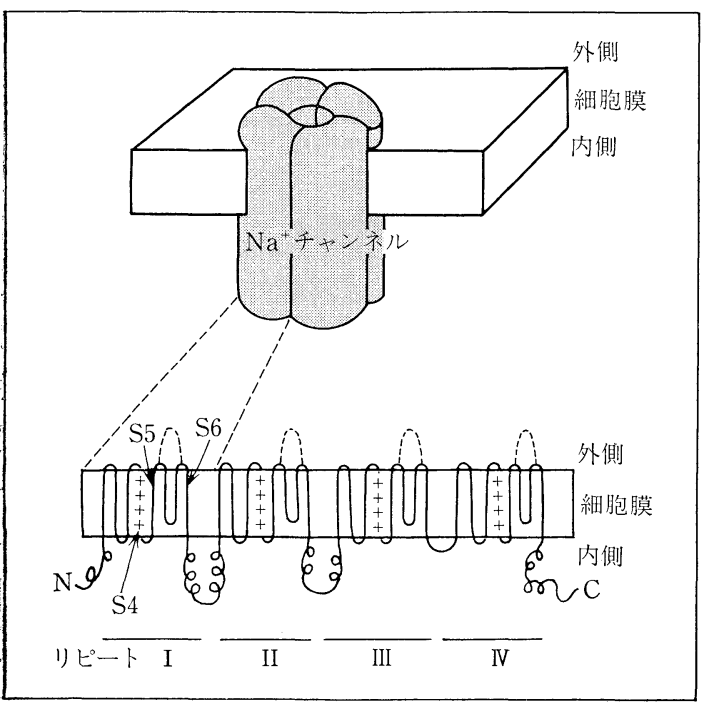

図 1 最近の知見をもとに想定された $\mathrm{Na}$ チャンネルの 膜配置モデル

$4 つ の く り$ 返し構造（リピートI〜IV）は，それぞれ S 1 S 5 のセグメントからなる. S5-S6 間のリンカー部は従来, 膜の 外側 (点線) と考㝋られていたが，現在では膜の中に入ってい ることがわかっている.
発電器官や, 脳, 骨格筋のチャンネルは TTX 感 受性であり，哺乳類の心筋や，培養した骨格筋 あるいは除神経処置した骨格筋のチャンネルは TTX 非感受性である (表 1). 電気ウナギ発電器 官に続いてラット脳や骨格筋, さらには心筋の $\mathrm{Na}$ チャンネルの一次構造が相次いで明らかにさ れた. TTX 非感受性の分子メカニズムを知る上 からも，両タイプのチャンネルに違いがあるかど らか, 特に TTX 結合部位と考えられる部分での 比較に衆目が集まったのは当然である.

結論を先にいうと, TTX 結合部位の一部を構 成するとみなされるリピート I 上の 2 箇所でアミ ノ酸の置換が起こっていることが判明した ${ }^{(4)}$.す なわち, (1)385 番目のアミノ酸残基が, TTX 感 受性のチャンネルでは芳香族アミノ酸 Phe (一部 では Tyr）であるのに対して, TTX 非感受性の 心筋チャンネルでは Cys に置換されており, (2) セグメント S 5 とS 6 の連結部の $\mathrm{N}$ 末端側の部分 で, 連続した 14 アミノ酸残基が欠除 (deletion) していた（図 2).

現在, TTX 結合部位がぞのようなアミノ酸残 基で構成されていると考兄れているかについて は, 後で詳述するが, 385 番目近辺がその一部で あるとの知見はすでに得られていた。酸性アミノ 酸 Glu-387 を, 立体的に類似した中性アミノ酸 Gln に変換した変異チャンネルでは, TTX 結合

表 1 『代表的な組織における Na チャンネルとトキシン との結合親和性

\begin{tabular}{|c|c|c|c|}
\hline \multirow[b]{3}{*}{ 組織 } & \multicolumn{3}{|c|}{ 結合親和性 $\left(K_{\mathrm{d}}\right)$} \\
\hline & & $-[$ site 1$]$ & 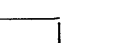 \\
\hline & $\begin{array}{l}\text { テトロドトキ } \\
\text { シン(nM) }\end{array}$ & $\begin{array}{l}\text { サキシトキ } \\
\text { シン(nM) }\end{array}$ & $\begin{array}{l}\mu-コ ノ ト キ ~ \\
\text { シン(nM) }\end{array}$ \\
\hline \multicolumn{4}{|l|}{ 神経 } \\
\hline ラット脳 & 0.64 & 0.114 & 11,000 \\
\hline ニワトリ & 0.24 & 0.043 & - \\
\hline $\begin{array}{l}\text { ロブスター運動 } \\
\text { 神経軸索 }\end{array}$ & & & $>10,000$ \\
\hline \multicolumn{4}{|l|}{ 骨格筋 } \\
\hline ラット & 1.8 & 0.49 & $19 \sim 140$ \\
\hline ラット（培養系） & 1,000 & 300 & \\
\hline $\begin{array}{l}\text { 電気ウナギ発電 } \\
\text { 器官 }\end{array}$ & 1.0 & - & $0.6 \sim 50$ \\
\hline \multicolumn{4}{|l|}{ 心筋 } \\
\hline ラット & 300 & 10 & $>10,000$ \\
\hline ラット（培養系） & 1,000 & 50 & \\
\hline ニワトリ & 0.60 & 0.95 & - \\
\hline
\end{tabular}




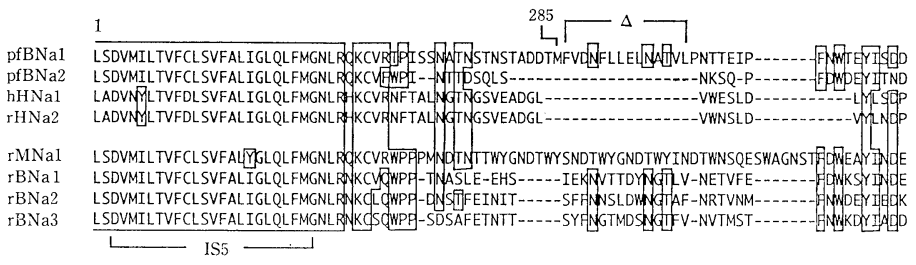

\section{$385 \quad 387$}

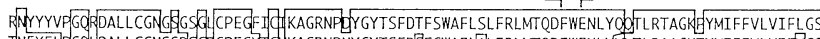

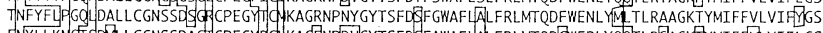

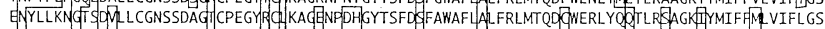

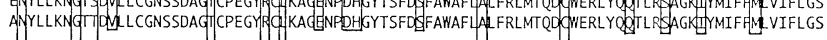

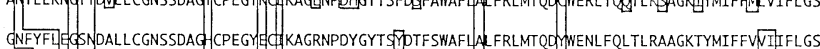

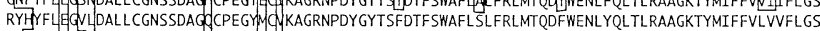
SHFYFLEG DALLCGNSDAGDCPEGMICNKAGRNPDYGTSFDTFSWAFLSLFRLMTODFWENLYQLTLRAAGKTYMIFFVLVVFLGS SHFYM DGGHCPLLCGNGSDAGDCPEGMIIUKAGRNPDYGYTSFDTFSWAFLSLFRLMTODMWENLYQLTLRAAGKTYMIFFVLVVFLGS $\llcorner$ SS1— ᄂ

図 2ロテトロトトキシン感受性と非感受性 Na チャンネルのリピートI S 5-S 6 連結部のアミノ酸配列の比較(8)

上段 4 つは TTX 非感受性チャンネル (pfBNa 1, 2: フグ脳 Na チャネル 1, 2; hHNa 1 : ヒト心筋 Na チャンネル1; rMNa 2 : ラット骨格筋 Na チャソネル 2) で, 下段 4 つは TTX 感受性チャソネル（rMNa 1：ラット骨格筋 Na チャソネル $1 ; \mathrm{rBNa} 1$ ～ 3 : ラット脳 Na チャンネル 1〜3) を示す. Na チャンネルすべてに保存されている Glu-387 と, 非感受性チャンネルではアミノ酸置 換が起こっている 385 番目と deletion が始まる 285 番目も示した。

能が大幅に低下することが実験的に確かめられて いたのである(5). TTX 結合部位を検索する目的 でこの変異実験が計画された根拠は, 1)TTX が 生理的条件では常に正電荷をもつグアニジニウム 基といら特別の官能基を有していることより，そ のチャンネル上の受容部位は負電荷をむつ酸性ア ミノ酸残基であろら, (2)従来からの薬理学的, 生 理学的研究から, TTX は細胞膜の外側から $\mathrm{Na}$ チャンネルと結合することが医涪確立していた， ことによるあのであろう.

この(1)の考光に基づいて，心筋 $\mathrm{Na}$ チャンネル の一次構造がわかった当初には, TTX 非感受性 の要因は次のように考兄られていた。すなわち， Glu-387 に隣接するAsn-388 が正電荷をすつ Arg に置換されているため, Glu-387 の負電荷が 実質的に相殺されてしまい，TTX グアニジニウ ム部の受容能が 低下したことによる，と。しか し, 実際はそうではなく, site-directed mutagenesis（部位特異的突然変異誘発）で Cys-385Trp-386-Glu-387-Asn-388 とした心筋チャンネ ルでも TTX 結合能はまったく向上しないことか ら, Cys-385 の変異が心筋チャンネルの TTX 非 感受性を決める主要因であると結論された ${ }^{(6)}$. 同 じ変異は, やはり TTX 非感受性である骨格筋チ ヤンネルの一部のクローンであ観察されている(7).

\section{フグの Na チャンネルの構造}

それでは，フグの $\mathrm{Na}$ チャンネルの分子構造は どうなのであろらか?

中沢（山口大・医）らがトラフグの脳からクロ ーニング(8) した 2 種の $\mathrm{Na}$ チャンネル遺伝子につ いて，TTX 結合部位の一部を構成すると考兄ら れるリピート I 中の S 5-S 6 連結部を調べてみる と，1つのクローンではこの部分に 14 アミノ酸 残基の deletion が認められた（図 2). 同じ場所 の deletion は, TTX 非感受性の心筋や一部の骨 格筋 $\mathrm{Na}$ チャンネルでも起こっていることはすで に述べたが，Phe-385 の Cys への変異はフグで は認められなかった（図 2). あら1つのクローン では, deletion あ認められなかった.ところで, TTX は有機強塩基化合物であり，疎水性が低い といら化学的性質をむ考慮すると, TTX 分子が 毒性を示す濃度にまでフグ脳内に透過・浸透でき らるか，といら疑問も残る。したがって，フグの TTX 非感受性と, このフグ脳 $\mathrm{Na}$ チャンネルの 変異とは，直接には結びつかないのかむしれな い。この問題に対する答えを得るためには，むし ろフグ筋肉の $\mathrm{Na}$ チャンネルの構造を調べるほう が適切であると思われる。

安元 (東北大・農) らは，ヒガンフグ筋肉を使 
ってその構造解析を行なっている(3). まだ結果の 詳細は発表されていないが，フグ脳で観察され たよらなアミノ酸残基の deletion は認められな いようであり，むしろリピートIやIII， N 上の TTX 結合に重要之考兄られる場所（後述）でア ミノ酸の置換が起こっているようである．最終的 結論はこの研究の完結を待たねばならないが，ど らやら，心筋や一部の骨格筋の場合にもみられた ような TTX 結合部位でのアミノ酸の置換が, TTX 非感受性を説明する一つの主要因であるこ とは間違いなさそらである。

\section{TTX 結合部位の分子構造}

さて，TTX 結合部位の分子構造については， 現在どのくらいのことがわかっているのであろら か? まず, リピートIの S 5-S 6 連結部にあ る, 385 番目から 387 番目 Glu を含む領域がそ の一部を構成し，重要な役割を果たしていること はすでに述べた.ところで $\mathrm{Na}$ チャンネルは, 図 1 で示したよらに，4回のリピート構造をもち， これらが寄り集まって1つのドーナッツ状のチャ ンネル分子をつくっていると考古れる。 したが って，リピート I 以外にも TTX 結合に深く関わ る部位が存在する可能性は十分にある。このよう な視点から沼（京大・医）のグループは，4つの リピートすべてについて，特に S 5-S 6 連結部に 注目して丹念な site-directed mutagenesis を行 ない(図 3), 変異チャンネル分子の TTX 結合能 および $\mathrm{Na}$ イオン透過能を調べた ${ }^{(9)}$.

その結果, リピートIに限らず，いずれのリピ 一トに括いても，SS 2 と呼ばれる部分にある特 定部位 2 籄所（図 3 中では $\mathbf{\nabla}$ 印 で示してある）のいずれか $1 つ$ のアミノ酸を変化させた場合 に，TTX 拈よびサキシトキシ ン (STX) 結合能が数百倍〜数 千倍も低下することがわかっ た ${ }^{(9)}$.このとき，チャンネル開 閉のキネティックスに変化はな かった. したがって，4つのリ ピートが集合したときに，各リ
ピート上の同等部位 2 箇所から構成される新しい リング（負電荷が多い）が TTX (STX) と特異 的に結合する部位であると提案された.

筆者らは，チャンネルタンパク質分子そのむの を用いて，TTX 結合部位を明らかにしたいと考 光，TTX 誘導体を用いる光アフィニティラベル を行なった. 光感受性基トリフルオロメチルーフ ェニルジアジリンは TTX 分子の C-11 位に導入 したが (図 4)，この試薬でラベルされた部分は， いずれもチャンネルのリピートIII， N 上の S 5S 6 連結部であり, リピートIには検出されなか った.この結果より，TTX はある配向性をあっ てチャンネルと結合する，すなわち TTX 分子の 特定部分と 4 つのリピート各々にある結合部位構 成アミノ酸残基との間には，ある定まった相互作 用が存在するのではないかと考光た(10). 図4 亿, そのモデルを示す(11).

このモデルを描く上での一つのポイントは，上 述の遺伝子変異に抢いて Lys-1422 を酸性のアミ ノ酸残基に置き換えた場合でもトキシン結合能が 大きく低下した事実であり，このことより Lys1422 (正電荷をむつ) は TTX の C-10 位へミア セタール（あるいはそのアニオン型）と水素結合 (あるいは静電気的相互作用)をしていると考え た. TTX ヘミアセタール部の $\mathrm{p} K_{\mathrm{a}}$ は水溶液中 で 8.2 と報告されているが，チャンネルタンパク 質との結合によってその值が低いほうへシフトす る可能性はある.

このモデルでは, TTX のグアニジニウム基は リピート I, II の酸性アミノ酸クラスターと相互 作用し, また光感受性基をむつ C-11 位はリピー

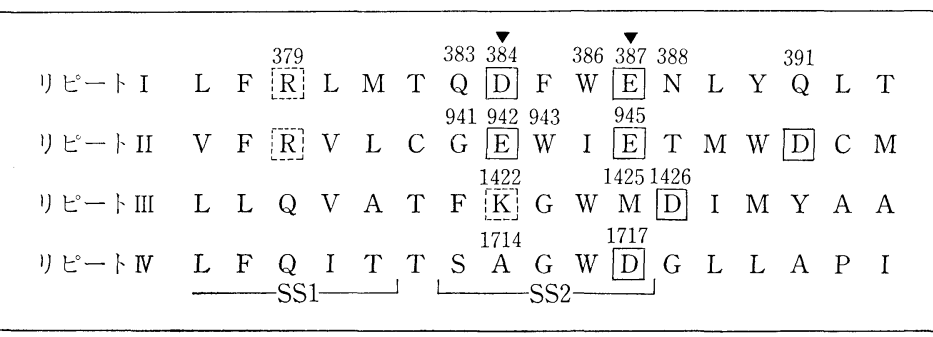

図 3ロラット脳 Na チャンネル SS 2 領域のアミノ酸配列 点変異が行なわれたつミノ酸には番号が付してあり, 目電荷をすつ残基は実線で, 正電 荷をもつ残基は破線で囲ってある. 印が 2 つの目電荷クラスターを形成する(9). 


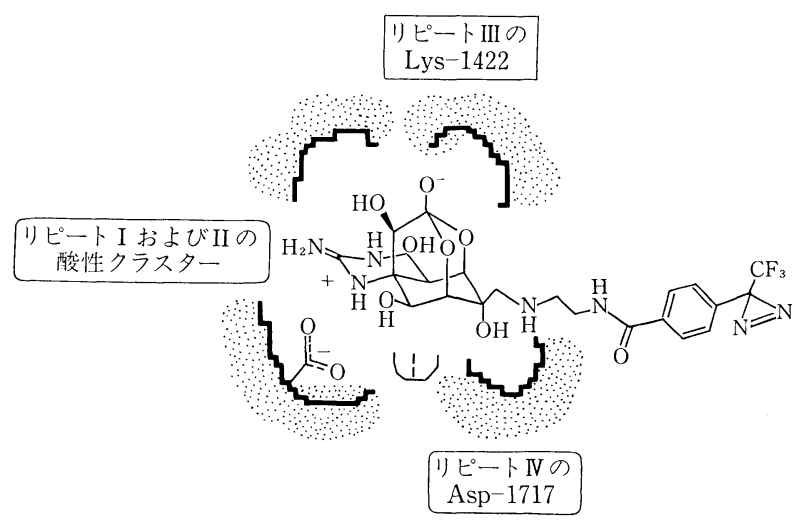

図 4 光反応性テトロドトキシン誘導体と, 結合時に相互作用すると推定さ れる Na チャンネル中のアミノ酸残基

トIII， $\mathrm{N}$ 側に配向している.これは，これまでの 実験結果をよく説明できる。また，安元は TTX 分子中の特定部分のみが変化した同族体 10 種類 余を用いて，チャンネル分子との結合に括ける構 造一活性相関を調べた 結果から，このモデルがよ く合致するとしている. このモデルで STX の結 合を考劣てみる，一方のグアニジニウム基（7, 8，9 位）はリピートI， IIの酸性アミノ酸クラス ターと, また C-12 位のケタール水酸基の一方が (TTX のへミアセタール酸素ほど十分ではない が）Lys-1422 と相互作用しらることになる。

モデルの妥当性を確かめる決め手は, TTX-チ ヤンネル分子複合体の三次元構造解析を待たねば ならないが，化学的手法によってあまだまだ肉迫 できそらである。

\section{TTX 結合タンパク質}

フグが TTX 抵抗性を示すもら一つのメカニズ ムとして考えられるのは, フグ筋肉中にチャンネ ルとは別の TTX 結合タンパク質が存在する可能 性である. 安元らは, フグ脳を用いて測定した TTX 結合量は, 別のタイプの $\mathrm{Na}$ チャンネル毒 ブレベトキシンの結合量と同等であったが，フグ 筋肉を用いて同様の実験を行なった場合には，ブ レベトキシンの結合量から推定される $\mathrm{Na}$ チャン ネルの量をはるかに上回る量の TTX が結合する ことを観察した。これより, フグ筋肉にはチャン
ネル以外にす TTX を結合する タンパク質が存在するのではな いかと考えた ${ }^{(3)}$. 筋肉膜を界面 活性剤で処理すると，このタン パク質の TTX 結合能は消失す ることからこの結合タンパク 質は筋肉膜上にあると推定され ている.

ある種のカエル (Rana catesbeiana) は STX 感受性が低 いことが知られているが，その 血漿中から STX に強い結合能 を示すタンパク質（分子量 89 $\mathrm{kDa})$ が分離されている(12). STX がカェル体内に入ってきても，このタンパ ク質でトラップされてしまらため， $\mathrm{Na}$ チャンネ ル機能を阻害しないことがこの動物における重要 な STX 非感受性機構である，と考古るは興味 ある仮説である、括むしろいことに，このカェル のタンパク質は TTX 結合能をもたないという. TTX に耐性を示すカリフォルニアイモリの神経 も STX ではブロックされる.このような，いわ ゆる TTX/STX 間の交差耐性が認められない例 も, このような内在性のトキシン結合タンパク質 によって説明できる可能性もある.

フグの TTX 耐性機構として, $\mathrm{Na}$ チャンネル の変異と TTX 結合タンパク質のどちらが大きく 寄与しているかを現時点で断定するのは難しい が，筆者は，前者がフグ体内に打ける最後の関門 として“切り札”の役割を果たしているものと考 えている、ただ，TTX 耐性 Na チャンネルとい えども, “全か無か”の法則のように切れ味鋭く TTX 結合から免れるわけではないので, Na チ ヤンネルに至る前の段階でガードできる TTX 結 合タンパク質の存在は, フグの生体防御上, 合目 的である. TTX 結合タンパク質の存在は新しい 知見であり，その寄与の度合いも含め，今後の展 開が待たれる。

\section{文献}

1) 中山 仁: 薬史学雑誌, 29, 441 (1994).

2) 末廣雅也 : 薬史学雑誌, 29, 428 (1994); 酒井 浄 : ibid., 
29, 435 (1994).

3) 安元 健 : 現代化学, No.282, 47 (1994).

4) R. B. Rogart, L. L. Cribbs, L. K. Muglia, D. D. Kephart \& M. W. Kaiser : Proc. Natl. Acad. Sci. USA, 86, 8170 (1989).

5) M. Noda, H. Suzuki, S. Numa \& W. Stuehmer : FEBS Lett., 259, 213 (1989).

6) J. Satin, J. W. Kyle, M. Chen, P. Bell, L. L. Cribbs, H. A. Fozzard \& R. B. Rogart : Science, 256, 1202 (1992).

7) M. E. Gellens, A. L. George, Jr., L. Chen, M. Chahine, R. Horn, R. L. Barchi \& R. G. Kallen : Proc. Natl. Acad. Sci. USA, 89, 554 (1992).
8) M.Sharjahn, M. Yamada, M. Nagaya, M. Kawai \& A. Nakazawa: Ann. N. Y. Acad. Sci., 707, 346 (1993).

9) H. Terlau, S.H. Heinemann, W. Stuehmer, M. Pusch, F. Conti, K. Imoto \& S. Numa : FEBS Lett., 293, 93 (1991).

10) H. Nakayama, Y. Hatanaka, E. Yoshida, K. Oka, M. Takanohashi, Y. Amano \& Y. Kanaoka: Biochem. Biophys. Res. Commun., 184, 900 (1992).

11) H. Nakayama, Y. Hatanaka, M. Taki, E. Yoshida \& Y. Kanaoka: Ann. N. Y.Acad. Sci., 707, 349 (1993).

12) Y.Li \& E. Moczydlowski : J. Biol. Chem., 266, 15481 (1991).

\section{ブロ フ ィ ル}

天 野 洋 (Hiroshi Amano) 昭和 26 年 5 月 14 日生 $<$ 略歴 $>1974$ 年京都大学農 学部農林生物学科卒業後, カナダ国トロ ソト大学動物学科にて M. Sc. 修了, 同 Ph. D. 修了, 帰国後, 千葉大学園芸学 部助手を経て, 助教授 (応用動物昆虫学 研究室)，現在にいたるく研究テーマと 抱負 $>$ 生態系の中での天敵類のもつ役割 の評価と, 農生態系でのその利用 く趣 味>スポーツ（特にテニス，スキー）, 旅行

岩崎 照雄 (Teruo Iwasaki) 昭和 7 年 8 月 3 日生 $<$ 略歴 $>$ 昭和 30 年九州大学農 学部農芸化学科卒業 $/ 39$ 年同大学大学院 農学研究科博士課程修了/同年米国ボス トン大学医学部生化学科研究員 $/ 43$ 年兵 庫農科大学農芸化学科助教授 $/ 44$ 年神戸 大学農学部農芸化学科助教授 $/ 61$ 年同教 授, 現在にいたるく研究テーマと抱負〉 プロテアーゼおよび蛋白質性プロテアー ゼインヒビター, マメゾウムシの蛋白質 性成長阻害因子, 植物の界面活性ペプチ ドなどの構造と機能の相関く趣味〉釣 り, 山歩き, 読書

鵜沢 浩隆 (Hirotaka Uzawa) 昭和39 年 9 月 6 日生<略歴>昭和 62 年東北大学 農学部食糧化学科卒業/平成3 5年日本 学術振興会特別研究員 $/ 4$ 年同大学大学 院農学研究科博士課程修了 $/ 5$ 年理化学 研究所勤務 $/ 7$ 年通商産業省工業技術院 物質工業技術研究所入所, 現在にいたる く研究テーマと抱目>分子認識などの機 能をもつ有機材料の創製とその評価（主 に有機合成 化学的方法による) <趣味> 自然を満喫すること

大久保 敬 (Hiroshi Okubo) 昭和 23 年 7 月 14 日生 $<$ 略歴 $>$ 昭和 49 年九州大学 農学部農学科卒業 $/ 51$ 年同大学大学院修 士課程修了/56年同博士課程退学, 同農 学部助手/平成 2 年同助教授, 現在にい
たるく研究テーマと抱負〉球根作物の休 眠生理，植物の生育のしくみを明らかに したいく趣味〉旅行

大森 俊雄 (Toshio Omori) 昭和16年 8 月 5 日生<略歴>1965年東京大学農学 部農芸 化学科 卒業 $/ 1970$ 年同農学部助 手/1986年同助教授／1993年同生物生産 工学研究センター教授, 現在にいたる く研究テーマと抱負〉微生物の共生系の 解析と応用

大類 洋 (Hiroshi Orui) 昭和17年 1 月 2 日生 $<$ 略歴>昭和 40 年東京大学農 学部農芸化学科卒業/同年宇部興産株式 会社勤務 $/ 41$ 年理化学研究所勤務 $/ 56$ 年 東北大学農学部食糧化学科 (現応用生物 化学科) 助教授, 現在にいたるく研究テ 一マと抱負>(1)キラリティーと分析, キ ラリティーと生命を含を自然現象, (2)超 高感度分析試薬の開発, (3)抗ガン抗ウイ ルス活性ヌクレオシドの開発

岡田 吉美 (Yoshimi Okada) 昭和 4 年 2 月 3 日生 <略歴>昭和 27 年大阪大学 理学部化学科卒業 $/ 41$ 年農林省植物ウイ ルス研究所研究室長 $/ 47$ 年東京大学理学 部生物化学科教授/平成元年帝京大学理 工学部バイオサイエンス学科教授, 現在 にいたるく研究テーマと抱負〉植物ウイ ルスの分子生物学, 植物を利用したワク チンの生産

金子 淳 (Jun Kaneko) 昭和 37 年12 月 18 日生<略歴>昭和 61 年東北大学農学 部農芸化学科卒業 $/ 63$ 年同大学大学院農 学研究科博士前期課程修了/平成元年同 農学部助手, 現在にいたるく研究テーマ と抱負>黄色ブドウ状球菌の二成分性血 球崩壊毒素の作用機作. リジンデカルボ キシラーゼ (ダイズ) <趣味>旅行, 写 真, 鉄道模型
神尾 好是 (Yoshiyuki Kamino) Vol. 31 , No. 4, p. 234 参照

菊池慎太郎 (Shintaro Kikuchi) 昭和 25 年 10 月 29 日生 $<$ 略歴>昭和 48 年北海道 大学農学部農芸化学科卒業 $/ 50$ 年同大学 大学院農学研究科修士課程修了 $/ 54$ 年同 博士課程修了(薬博) $/ 56$ 年川崎医科大学 医学部助手 (生化学) /62年室策工業大学 工学部助教授 (微生物工学), 現在にい たる.この間，60〜62年米国ワシントン 州立大学生物化学研究所研究員 <研究テ 一マと抱負>微生物の楽物代謝, 特に結 核菌などの抗酸菌の物質代謝に興味く趣 味 $>16,7$ 世紀の陶磁器の収集と鑑賞

佐藤 清隆 (Kiyotaka Sato) 昭和21 年12月23日生<略歴>1974年名古屋大学 大学院工学研究科博士課程応用物理学専 攻単位取得退学/同年広島大学水畜産学 部 (現生物生産学部) 助手, 助教授を経 て，1991年教授，現在にいたる. 1981〜 82年フランス・マルセーユ結晶成長機構 研究所に給費留学生として滞在く研究テ 一マと抱負>生体構成物質の構造物性と 機能の相関解析. 特に, 脂質とその関連 物質を幅広い応用に生かすことく趣味〉 サッカー, ランニング, スキー, 音楽鑑 賞

斉藤 和季 (Kazuki Saito) 昭和29年 10月12日生＜略歴>1977年東京大学薬学 部製薬化学科卒業後, 同大学大学院を経 て, 1982 年慶応義塾 大学医学部助手, 1985年千葉大学薬学部助手, 講師, 助教 授を経て，1995年同教授，現在にいた る.この間，1987年ベルギー国ゲント大 学遺伝学教室留学<研究テーマと抱負> 広い意味での薬用植物の遺伝子資源応用 という新しい研究分野を発展させ, 質的 レベルの高い研究をしたいく趣味〉野山 の散策, ジャズを聴くこと 